\title{
Barbarous Spectacle and General Massacre: A Defence of Gory Fictions
}

\section{IAN STONER}

ABSTRACT Many people suspect it is morally wrong to watch the graphically violent horror films colloquially known as gorefests. A prominent argument vindicating this suspicion is the Argument from Reactive Attitudes (ARA). The ARA holds that we have a duty to maintain a well-functioning moral psychology, and watching gorefests violates that duty by threatening damage to our appropriate reactive attitudes. But I argue that the ARA is probably unsound. Depictions of suffering and death in other genres typically do no damage to our appropriate reactive attitudes, and until we locate a relevant difference between these depictions in gorefests and in other genres, we should assume that the depictions in gorefests do no damage. I consider and reject three candidate differences: in artistic merit, meaningfulness, and audience orientation. Until genre sceptics identify a relevant difference, we should accept the taste for gory fictions as we would any other morally innocuous variation in taste.

Some folks have a strange idea of entertainment.

- Martin the Gravedigger in Friday the 13th Part VI: Jason Lives

In Blood Feast (1963), a deranged cultist cuts the tongue from the mouth of a young woman. We watch him fondle the bloody tongue in a long, close shot. In Motel Hell (1980), a hotelier serves human flesh to unwitting guests. We see the victims cut apart on the hog processing line, and we see guests gnaw on jerky made from their flesh. In Evil Dead II (1987), our hero, caught up in a swirl of evil forces, is left with no choice but to sever his own hand. He uses the best tool available to him in a bad situation: a chainsaw, naturally.

These and similar scenes of graphic gore make many people uncomfortable uncomfortable in a way that scans plausibly as a species of moral discomfort. In the United Kingdom, Blood Feast was prosecuted as a 'Video Nasty', not because people didn't enjoy it, but because a democratically elected government was persuaded that it was morally wrong to watch it. ${ }^{1}$

Though the protected-speech side of the debate has since carried the day in the United States and the United Kingdom, and it is now rare to find an open advocate of government censorship of horror films, moral discomfort with them remains widespread. Can this discomfort survive reflective scrutiny? Is it morally wrong to produce or watch the graphically violent horror films colloquially known as gorefests? 
I take the most interesting form of the question to be subject to two constraints: one concerning the kinds of films that need defending, and one concerning the sort of charge from which they need defence.

First, on the type of film I will defend. It is characteristic of paradigm cases of gore film that they aim to cause feelings of fear or disgust and that they feature graphic depictions of suffering and death as a means of achieving that aim. This is not a philosophical definition; it is too inclusive. (Were this a philosophical definition, Un Chien Andalou would be a counterexample.) But nothing morally important turns on a philosophical definition of gore, and I will not attempt to escape the moral challenge through the clever shaping of definitions. Whatever gore films you take to pose the challenge most starkly - perhaps you were most morally unsettled by the violence depicted in Hostel, or Martyrs, or I Spit on Your Grave - those are the films whose graphic depictions of violence I will defend.

I insist on only one constraint on your choice of paradigm cases: the gore in gore films is the fictive representation of violence, suffering, and death. Films that include real footage of suffering and death, including the notorious handful of Italian cannibal films that feature real animal killings, are genre outliers that present a distinct moral problem. It is watching and enjoying gory special effects that I will defend. ${ }^{2}$

Second, on the sort of charge from which these films need defence. Films of every genre potentially include morally problematic aspects, and some of those problematic aspects are well represented in horror's subgenres. Too many horror films depict the rural poor as subhuman menaces and mentally ill people as inscrutable threats. Too many use physical disfigurement and disability as stand-ins for moral degeneracy. Too many display a misogynistic streak. These are failings the horror genre shares with other genres, a reflection of broader social failings. All films produced by imperfect people in an imperfect society run the risk of misinforming audiences, entrenching bigotries, and further marginalising the already marginalised. Gore films, like other films, sometimes do that.

None of these problematical features is shared by all, or even most, paradigm cases of gore film. The feature common to gore films is gore, and so an interesting argument that watching gore films is morally wrong must appeal to fictive depictions of violence; it must ground the wrongness of gory fictions in those gouts of corn syrup dyed arterial red.

In the philosophical literature, a prominent argument addressing the most interesting form of the question - what is the moral status of fictive depictions of gore? - is the Argument from Reactive Attitudes (ARA). The ARA holds that watching gore films is wrong because the depictions of suffering and death that they contain threaten to damage our ability to react with appropriate compassion to real-world suffering. My core thesis is that the Argument from Reactive Attitudes fails in an interesting and instructive way. In Section 1, I summarize the ARA, and in Section 2 I argue that it is unsound. Section 3 addresses a separate argument that originally motivated the ARA. Section 4 addresses the worry, which some readers might quietly harbour, that debating the ethics of gore films is a frivolous use of scarce time and attention. 


\section{The Argument from Reactive Attitudes}

The Argument from Reactive Attitudes, introduced by Gianluca Di Muzio and elaborated by Scott Woodcock, is a straightforward argument from principle:

(1) 'It is prima facie morally wrong to view, or to facilitate viewing, those features of a work of art or entertainment that encourage the corruption of reactive attitudes that are necessary for human agents to develop and maintain a well-functioning moral psychology. ${ }^{3}$

(2) 'Taking pleasure in murder, torture, dismemberment and other acts of horror violence can threaten the proper functioning of our sympathetic attitudes. ${ }^{4}$

(3) Therefore, it is prima facie morally wrong to view, or to facilitate viewing, horror films. ${ }^{5}$

One appealing aspect of the ARA is that it articulates and justifies the views of people deeply involved in controversies about gore films. James Ferman, for example, the director of the British Board of Film Certification during the Video Nasty panic and a fervent supporter of the ban on video violence, was specifically concerned with the effect of horror violence on viewer compassion: 'The pornography of violence is indulging in the physical process of wounds and wounding, mutilation, and torture. Again: for kicks. For voyeuristic interest. That is the problem with them. That they don't encourage compassion. That they encourage detachment and enjoyment., ${ }^{6}$ In Aristotlean terms, the ARA justifies certain endoxa.

The central appeal of the ARA, though, is that the moral principle that grounds it is an entertainment-specific instance of a more general moral principle that is overwhelmingly plausible: we ought to avoid damaging our own, or anyone else's, appropriate reactive attitudes. This principle is appealing because it effectively systematizes our reflectively endorsed judgments about cases. Consider just one example. Substantial anecdotal evidence and some broader sociological data suggests that slaughterhouse work - that is, work stunning or killing animals - badly damages the reactive attitudes of the people who do it. ${ }^{7}$ If slaughterhouse work predictably has the effects self-reported in interviews and etched in crime data - if killing animals makes people quicker to anger and to commit violence, mistrusting of their family and friends, desensitized to human suffering, utterly indifferent to animal suffering - then those predictable effects clearly yield a pro tanto moral reason to avoid this line of work. Imagine, for example, that you are the parent of a son about to graduate high school, who asks your advice about which of two summer job offers to accept: sticker in the local slaughterhouse or package sorter at the local post office. Suppose the slaughterhouse is slightly closer than the post office, so it will take you less time to pick him up and drop him off from work. Suppose the slaughterhouse pays a bit better, so he will be less likely to need your financial support if he works there. Still, it seems to me, it would be morally wrong to urge your son to take the slaughterhouse job. It would be morally wrong because that job is likely to damage him psychologically, and it is part of your duty as a parent to do what you can to help your child develop and maintain a healthy moral psychology. The same is true of the choices we make for ourselves. Maintaining a healthy moral psychology is morally important, and in the absence of 
powerful countervailing moral considerations, we would be wrong to choose slaughterhouse work for ourselves. ${ }^{8}$

Di Muzio and Woodcock suggest that this overwhelmingly plausible principle about how we should conduct ourselves in life - we should not damage the reactive attitudes of others or ourselves - applies to our choice of entertainment. If any entertainments could inflict upon our psychologies even a shadow of the damage slaughterhouse work can, then we should not indulge in such entertainments. Premise 1 of the ARA is, I believe, true.

The ARA's second premise is also appealing because the empirical claim it asserts does not require robust empirical support. This is important given the difficulty of gathering reliable evidence about the psychological effects of media diets. In a joint statement issued in July of 2000, the American Psychological Association, American Medical Association, American Psychiatric Association, and three other professional associations declared that the science was in and the issue settled: the ill effects of exposure to media violence 'are measurable and long-lasting.... Children who see a lot of violence are more likely to view violence as an effective way of settling conflicts.... Viewing violence can lead to emotional desensitization towards violence in real life... Viewing violence may lead to real life violence. ${ }^{9}$ For those who have glimpsed graphs of crime rates since the 1990s, this joint statement is in retrospect puzzling. In the last 25 years, film and broadcast violence has intensified, the popularity of violent video games has surged, and violent crime rates have plummeted. ${ }^{10}$ Whither the surplus aggression?

In fact, careful attention to statistical evidence shows no relationship (or even, possibly, a negative relationship) between violent media and violent crime. ${ }^{11}$ This suggests that contemporary sceptics were right, and methodological flaws marred the research that motivated the joint statement. ${ }^{12}$ Indeed, a comprehensive meta-analysis that attempted to correct for the most glaring of those methodological flaws concluded: 'Results from the current analysis do not support the conclusion that media violence leads to aggressive behavior. ${ }^{13}$

Evidence that violent media does not increase aggression or promote violent behaviour is not decisive against the empirical premise of the Argument from Reactive Attitudes, for Di Muzio and Woodcock are not committed to the claim that gorefests turn gore fans violent. They are only committed to the claim that gorefests make gore fans at least a little bit less compassionate than they otherwise would have been. And slight damage to the appropriate functioning of a subject's reactive attitudes relative to a counterfactual no-exposure doppelganger is - to understate the case - difficult to measure. Empirical research may never decisively confirm or falsify the ARA's second premise, and for now we have little choice but to evaluate the ARA independently of reliable empirical evidence.

But the context of the ARA is the choosing of entertainments, and even passionate gorehounds will concede that there are many other delightful ways to pass the hours. In the context of entertainment, when the number of dishes on our buffet of available options far exceeds our ability to sample them in one lifetime, a plausibility standard makes more sense than a strong evidentiary standard. We need not insist on a preponderance of evidence or, really, any evidence at all. As Woodcock puts the point, 'In the absence of conclusive empirical evidence, the link between actively taking pleasure in sadistic violence and undermining one's moral capacities is sufficiently plausible, I 
think, for it to be morally appropriate to adopt a precautionary attitude toward the choice to view such violence as entertainment when other options are available. ${ }^{14}$

The ARA holds its place in discussions of violent entertainment because both of its premises are appealing. In the next section I argue that its second premise is, nevertheless, false.

\section{The Trouble with the ARA}

The ARA turns on the claim that watching fictive depictions of suffering and death risks damaging our appropriate reactive attitudes. So long as our attention is focused narrowly on gorefests, this claim might appear plausible. The trouble is that when we widen our view, it is immediately clear that the story cannot be so simple. Epic poetry (The Iliad), heroic tragedy (The Bacchae), romantic tragedies (Titanic), pet-death tearjerkers (Old Yeller), war films (Saving Private Ryan), historical dramas (Munich), natural disaster films (The Day After Tomorrow), action flicks (Die Hard), dark comedies (Fargo), and dystopian futures (The Handmaid's Tale) - all of them depict suffering and death, in every case for the enjoyment of the audience and typically without posing a threat to our appropriate reactive attitudes.

We humans are capable of taking in painful artworks and experiencing the responses they cause - fear, disgust, shock, sadness, grief - as positive emotions. To suppose that fictive depictions of suffering and death in general are psychologically corrosive and therefore immoral would fly in the face of civilisations of evidence to the contrary. If the ARA is to avoid being a reductio of the principle that grounds it, its defenders owe us an answer to this question: what makes the fictive depictions of suffering and death characteristic of gore films psychologically dangerous, when the fictive depictions of suffering and death characteristic of many other genres (typically) are not?

In the remainder of Section 2, I consider and reject three candidate answers to this question.

\subsection{Differences in Artistic Merit}

The candidate answer: There are two significantly overlapping descriptions of genre often embraced by fans of gorefests: 'trash film' and 'exploitation film'. The terms suggest that gorefests are not generally in the business of artistic achievement. If artistic achievement mattered to the psychological effects of violent fictions, then this difference could justify premise 2. Fictive depictions of violence in gore films are psychologically risky because they occur in trash films, while depictions of suffering and death in nobler genres are not risky because they occur in films whose artistic merit can redeem the violence.

The trouble with this answer: I opened the article with three examples of wince-instigating gore: the cutting out of a young woman's tongue, the unwitting swallowing of human flesh, and the deliberate self-severing of a hand. Shakespeare fans will have been expecting some kind of manoeuvre, for these are all three instances of violence depicted in Titus Andronicus, a play audiences have enjoyed for centuries while remaining psychologically intact. 
It is true that Titus Andronicus includes powerful speeches and quirky characterisations that are thin on the ground in the gorefest canon, but it is difficult to believe that its excellent writing is prophylaxis against psychological damage. Imagine that a community group of Shakespeare lovers undertakes a production of Titus Andronicus, even though they lack talent and experience. They cannot effectively deliver the powerful language or portray the quirky characters, and they otherwise lack the theatrical abilities required to stage Titus well. Or, rather, they lack most of the required abilities. When it comes to theatrical gore, they have a surprising technical and creative flair. I struggle to believe it would be psychologically risky for them to take their best shot at Titus or psychologically risky for the rest of us to enjoy their artistically meritless production on its own terms. If Titus well produced is not psychologically damaging, it is hard to accept that Titus poorly produced could be.

A narrow focus on psychological damage might obscure the strength of the case against any form of the claim that the moral permissibility of an art experience is contingent on aesthetic features of the art. I expect readers familiar with both Titus Andronicus and Blood Feast will widely, even overwhelmingly, accept the following trio of beliefs:

(1) Titus Andronicus is excellent art when judged by reasonable aesthetical standards.

(2) Despite its graphic depictions of gore, it is not immoral to stage a production of Titus, nor is it immoral to read or watch the play. ${ }^{15}$

(3) Blood Feast falls short of artistic excellence when judged by reasonable aesthetical standards.

Defenders of the ARA would add a fourth claim that is, on its face, difficult to square with the other three:

(4) Graphic depictions of gore make it immoral to produce or watch Blood Feast.

Claims 1-4 could all be true if the aesthetic quality of a work of art determines the moral valence of the depictions it contains. This would be a remarkable result and would spawn new research programmes inverting the familiar ethicism debates. ${ }^{16}$ But no one, I think, believes that aesthetic flaws are moral defects, for if it were so the refrigerators of parents of school-aged children would be all alike monuments of crime.

One could, of course, reject the implausible claim that aesthetic flaws are moral defects while still accepting that there are potentially many moral reasons to avoid consuming (aesthetically) bad art. Bad art might waste time that could be better spent in other pursuits. Allowing one's baser tastes too much time at the tiller might make it psychologically difficult to allow one's nobler sensibilities a turn. Paying to consume bad art encourages the production of more bad art. And so on. But these reasons are far afield of what motivated the ARA in the first place. None has any connection to the moral status of graphic violence, and that is what we need if we are to endorse the claim that people ought to refrain from watching gory films, as distinct from poorly crafted films.

It is true that many gore films are poorly crafted compared to some films of other genres. But this difference is not morally relevant in general and cannot explain disparate psychological effects in particular. Differences in artistic merit cannot save premise 2 of the ARA. 


\subsection{Differences in Meaningfulness}

The candidate answer: The characteristic feature of gore films is that they aim to cause fear and disgust. For a gore film to succeed qua gore film, it need not connect those feelings to any lesson, insight, or meaning. Compare with a violent film broadly embraced as admirable: Schindler's List. This film causes most viewers feelings of fear and disgust, in response to its depictions of violence, but it doesn't end at that. It uses those feelings to urge various moral, historical, characterological, and political insights. Schindler's List is meaning-making in a way gore films are not.

Di Muzio worries about meaninglessness. Of Texas Chain Saw Massacre, a horror film he believes is immoral to watch and was immoral to produce, he writes: 'The film's power and effectiveness as a paradigm of the genre lie in the fact that the violence that permeates it is completely unintelligible to both the characters in the story and the audience in the theater. There is no reason whatsoever behind the murders and acts of cruelty that occur in the film. ${ }^{17}$ Perhaps events similar to those depicted in Texas Chain Saw Massacre could, if used to urge moral or other insights, be redeemed through their connection to meaning. But left as it is, unintelligible and meaningless, Di Muzio believes the violence portrayed there risks damage to proper compassion.

Why is gorefest violence psychologically risky and violence in other genres typically is not? Candidate answer \#2: because violence in other genres is (typically) in the service of meaning, and violence in gorefests is not.

The trouble with this answer: Gore fans generally reject the claim that gore films characteristically lack ambitions beyond stimulating fear and disgust. They are right to. The stimulation of fear and disgust is characteristic of the genre, but not all gore films are content to stop there. In fact, some of the films gore-sceptics cite as the most worrying are also films that clearly have further goals. The Saw franchise is ludicrously overwrought with themes of justice, retribution, and responsibility, and the Hostel franchise self-consciously invites discussion of capitalism, commodification, and exploitation. ${ }^{18}$ Even Texas Chain Saw Massacre has ambitions beyond those Di Muzio credits. Says director Tobe Hooper: 'It's a film about meat. ${ }^{, 19}$ It is not a charitable read of the genre to suppose that, because its defining characteristic is the stimulation of fear and disgust, its films achieve nothing more. ${ }^{20}$

More than a few gore films, however, do lack political, social, moral, or other ambitions; for many gorefests, fear and disgust is enough. Even for these unambitious gorefests, it is hard to believe that their failure to be meaning-making could make them psychologically damaging. Imagine a showing of Schindler's List in which the projector loses power after 2 hours and 15 minutes, depriving the audience of the film's meaning-making final hour. That audience would have witnessed a long series of graphically violent images of suffering and death, with virtually none of the narrative elements that could support a reading of the film as a story. They would have seen, in effect, a bigbudget, beautifully photographed series of simulated Nazi atrocities. I cannot believe that this unlucky audience would be psychologically damaged by the early reels of the film, while audiences who saw the full film were retroactively protected from early-reel damage by the meaningful content of the final reels. The unlucky audience might leave the show frustrated, disturbed, or disappointed, but they would not leave with an impaired ability to react with compassion to real-world suffering. 
A failure to be meaningful cannot explain why fictive depictions of suffering and death in gorefests are psychologically damaging, while fictive depictions elsewhere typically are not.

\subsection{Differences in Audience Orientation}

The candidate answer: Two distinct experiences could potentially be grouped together under the ambiguous idea of taking pleasure in sadistic fiction. Consider as an example of sadism in fiction the schoolboys' treatment of Piggy in Lord of the Flies. What makes their treatment sadistic is that they directly enjoy Piggy's suffering; Piggy's pain causes them not sympathetic pain, but cruel pleasure.

Among readers who have enjoyed Lord of the Flies, most sympathize with Piggy, disapprove of his bullies, and feel shocked and saddened when he dies. In response to the sadism the book depicts, these readers suffer sympathetically in a way they enjoy; they are experiencing the paradox of painful art. Call this paradoxical pleasure.

Other readers could enjoy the book differently. One can imagine readers who loathe Piggy, who wish they could bully him along with the schoolboys. Those readers might enjoy Piggy's pain directly, as the sadistic schoolboys do, and they might feel a rush of achievement or satisfaction when Piggy dies. Call this vicarious sadism.

If gore films invite an orientation of vicarious sadism, then we would have a relevant difference between gore films and other genres, such as tragedy, which invite paradoxical pleasure. Even though it is not plausible that experiences of paradoxical pleasure risk damaging our compassionate responses, experiences of vicarious sadism might.

Some people who do not derive paradoxical pleasure from gore films have assumed gore fans must experience vicarious sadism in response to depictions of sadistic violence. A famous tabloid headline during the Video Nasty panic read 'Ban the Sadist Videos!' - which seems importantly different from a call to ban frightening or violent videos. Gore-sceptical critics have pointed to specific genre tropes as evidence that these films invite a stance of vicarious sadism. For instance: gore films often feature point-of-view shots from the killer's perspective, literally putting audiences behind the eyes of the monster. Surely filmmakers use this technique to invite sympathetic identification with the killer. ${ }^{21}$ Or: The typical audience for gore films is young men, but the victims are disproportionately women. Surely filmmakers intend their male audiences to identify with the male killer and celebrate his punishment of female victims. ${ }^{22}$

Why is gorefest violence psychologically damaging and violence in other genres is not? Candidate answer \#3: gore films threaten reactive attitudes because they typically invite an orientation of vicarious sadism, while other genres do not threaten reactive attitudes because they typically invite an orientation of paradoxical pleasure.

The trouble with this answer: The basic problem with attributing vicarious sadism to gore fans is that observation falsifies the assumption. Exactly as the popular idea of their enthusiasm for these movies would have it, what's really true is that gore fans hope the new horror flick will be scary enough to make them cover their eyes or look away, they hope it will be gruesome enough to make them wince or gag, and they are disappointed if it is too tame to trigger any of these physiological responses. That gore fans give every impression of feeling fear and disgust in response to gorefest violence is good evidence that they are enjoying paradoxical pleasure in painful responses. 
This is why advertising materials for horror films invariably promise the experience of fear and disgust. The trailer for Paranormal Activity (2007) featured night-vision footage of terrified audiences watching the film and quoted a reviewer testifying that afterward, 'people were physically shaken'. ${ }^{23}$ Movie-branded barf bags distributed from the box office were a common gimmick at gore film screenings of the 1970s. The marketing materials for The Last House on the Left (1972) commanded audiences to repeat the mantra 'It's only a movie,' to help manage the overwhelming terror the movie promised to provoke. Horror movies promise a paradoxically pleasant experience of fear and disgust, and that is what fans show up expecting. ${ }^{24}$

This promise of distinctively paradoxical pleasure is fundamental to the drawing of genre boundaries. Death Wish (1974) is an action movie about a man avenging his wife's murder with a series of murders of his own. It is an action movie because the film codes those revenge murders as moments of excitement, intended to elicit audience feelings of exhilaration and satisfaction. The Last House on the Left (1972) is a horror movie about parents avenging their daughter's murder with a series of murders of their own. It is a horror movie because the film codes those revenge murders as moments of horror, intended to elicit audience feelings of fear and disgust. ${ }^{25}$ It isn't clear that a movie that invited vicarious sadism - instead of the paradoxical enjoyment of fear and disgust - could ever be a candidate for a horror film. Vicarious sadism is compatible with the aims of some genres; it is in tension with the aims of horror.

What, then, of the genre tropes sceptics cite as evidence of vicarious sadism? These are, I believe, misreadings. It is true that victims in the slashers of the 1970s and 1980 s were disproportionately women, while the audience was disproportionately young men. Carol Clover's landmark readings of these slashers long ago showed the challenge in reading gendered body counts as evidence of misogynistic sadism: the typical structure of the slasher film features a Final Girl, tested in the crucible of terror, who rises to face and destroy the killer. That structure makes little sense absent the precondition that viewers identify with and root for the Final Girl. ${ }^{26}$ If audiences were typically taking sadistic pleasure in the destruction of female bodies, there would be no Final Girl.

It is also true that gorefests often feature shots from the killer's point of view. But this shot has obvious narrative advantages, not least that it demonstrates the concrete presence of the threat without revealing the monster. 'Rather than communicating sympathetic alignment [with the killer, killer POV] shows the viewer that, within the scene, someone is looking. ${ }^{27}$ The clearly demonstrated presence of the killer, unseen by the characters and the viewers, is scary for viewers because they recognize the threat to the characters. This does not suggest vicarious sadism, but sympathy with the victims. Wherever the camera's location, it is the viewer's emotional engagement with victims that 'makes horror horrifying'. ${ }^{28}$

Two clarifications. First, I believe that audience responses to art of any kind are typically complex; so too with audience responses to gorefests. Gore fans often have a special interest in and appreciation for the craft of special effects. Gore fans, more than fans of some other genres, enjoy metafictional flourishes, 'including the use of wit, parody, and intertextual reference'. ${ }^{29}$ Like fans of any narrative genre, they enjoy a story well told, and they particularly enjoy the satisfaction of the morbid curiosity horror narratives stoke. ${ }^{30}$ Many enjoy the specific kinds of self-reflection these films prompt, at both the narrative level (what would I do if I were caught in the killer's 
trap?) and the film-experience-level (should I be watching this?). ${ }^{31} \mathrm{My}$ claim is not that the response of gore audiences is unadulterated masochism, but rather that gore fans, like tragedy fans, are drawn to the genre by their desire to enjoy the experience of negative emotions. ${ }^{32}$ I cannot rule out the possibility that there is some subtle thread of sadism running through complex responses to horror (or, for that matter, to tragedy or any other genre of painful art). But viewing the movies, observing their fans, and reading sensitive critics of the genre shows that vicarious sadism is contrary to the characteristic aims of the genre, and there is certainly no need to appeal to vicarious sadism to explain the typical fan's positive experience of a gorefest. ${ }^{33}$

Second, I believe it is appropriate to adopt a precautionary attitude toward films that encourage vicarious sadism. To practice sadistic habits of mind in the movie theatre seems psychologically risky, a probable violation of the moral principle that grounds the ARA. If a film of any genre, whether graphically violent or not, invites vicarious sadism, then a precautionary attitude toward it seems to me justified. And if a particular gorefest somehow did, in contravention of genre expectations, invite vicarious sadism, I would support a precautionary attitude toward that specific film. ${ }^{34}$ But the violence characteristic of the genre could only be morally worrying if gorefest violence is of the sort that invites vicarious sadism, ${ }^{35}$ and in this section I have canvassed some reasons for thinking it is not so.

Gorefest audiences, like audiences for tragedies, typically experience primarily paradoxical pleasure in response to painful art. Differences in audience orientation cannot save premise 2 .

\subsection{Provisional Conclusion}

The ARA turns on the premise that enjoying gory fictions risks damage to our appropriate reactive attitudes. I have argued that this premise could only be true if there is some relevant difference between the fictive depictions of suffering and death in gore films and the depictions of suffering and death in genres widely held to be unobjectionable. I see no candidates for such a difference, and so I provisionally conclude that the ARA is unsound because its second premise is false.

I cannot rule out the possibility that there is some relevant difference between gorefests and other genres that could save premise 2, so my conclusion can only be provisional. The burden of argument, however, should certainly be on those who suggest that the violence characteristic of this genre is specially threatening to the appropriate functioning of our reactive attitudes. What is the feature of gorefests that makes their depictions of suffering and death psychologically dangerous, when depictions of suffering and death elsewhere (typically) are not? Until we have a good answer to that question, we should assume that premise 2 is false.

\section{A Loose End: Nazi Cruelty Film}

Woodcock's version of the Argument from Reactive Attitudes is an elaboration of an earlier argument by Gianluca Di Muzio. Di Muzio introduces his discussion of the ethics of horror consumption with an argument from analogy. He invites us to imagine a graphically violent movie about atrocities in Nazi death camps, whose intent has 
nothing to do with education or edification. We are to imagine that the producers of Nazi Cruelty Film hope 'simply to give the audience a thrill ride, sending it out of the theater with the feeling of having witnessed a spectacle of extreme violence and unparalleled emotional intensity'. ${ }^{36}$ Di Muzio summarizes the argument this way:

For reasons that are not easy to specify... it seems correct to say that it would be morally wrong to produce, distribute, and view a Nazi cruelty... film; [but] in terms of their content, of the filmmakers' intent, and of the effects on the audience, gorefest films such as The Texas Chain Saw Massacre and the many similar products it inspired do not significantly differ from a Nazi cruelty... film; so... one should subject gorefest films to the same kind of moral condemnation to which one would subject Nazi cruelty. . films. ${ }^{37}$

The rest of Di Muzio's article and Woodcock's follow-up are given over to specifying those reasons that are not easy to specify. Why is it wrong to watch Nazi Cruelty Film? Di Muzio and Woodcock agree that it is because it threatens to damage our compassionate responses to real-world suffering. I have argued that the ARA is unsound because watching fictive depictions of suffering evidently does not damage our reactive attitudes. But Di Muzio's original analogy requires a separate treatment. If he is right that watching Nazi Cruelty Film is wrong, and he is right that it is relevantly similar to gorefests, then it must be wrong to watch gorefests, even if the ARA fails to explain why it is wrong.

Prospects are dim for discovering a morally relevant difference between Nazi Cruelty Film and gorefests, as it is less an analogy for gore films than an imaginary instance of a particularly seedy microgenre. Were someone to produce Nazi Cruelty Film, it would take its place alongside several other Nazisploitation gore films, such as Ilsa, She-Wolf of the SS (1975), SS Experiment Camp (1976), and Caligula Reincarnated as Hitler (1977). ${ }^{38}$

The weakness of Di Muzio's argument is not in the analogy, but in his described case. The judgment that it is morally wrong to watch Nazi Cruelty Film, a judgment most readers (I venture to guess) form on first contact with the case, is a judgment we should hesitate to endorse after critical reflection. The judgment that it is morally wrong to watch Nazi Cruelty Film is not clearly a credible moral judgment, it cannot support an effective argument from analogy. ${ }^{39}$

For the paradox of painful art to get off the ground, a viewer must have some degree of emotional distance from the suffering depicted in the art. A person who has just lost their family at sea will probably be unable to take tragic pleasure in Titanic. A parent who has lost a child to suicide will probably be unable to take tragic pleasure in Romeo and fuliet. Emotional connection to specific details of suffering and death depicted in an artwork can make it impossible to enjoy that artwork.

Empirical support for this armchair observation comes in the form of Menninghaus et al.'s Distancing-Embracing Model of paradoxically pleasurable experiences of painful art. They identify psychological distancing processes that appear to be a precondition of positive engagement with painful art. ${ }^{40}$ Matthew Strohl offers a helpful reconceptualisation of the Distancing-Embracing Model as a distancing condition instead of multiple distancing factors: 'Let the term dealbreaker designate an experiential element which is sufficient to render an experience [of painful art] overall aversive. Believing that one might actually die is usually a dealbreaker. Being reminded of a 
traumatic experience - or even just an unfortunate life event - is often a dealbreaker. The distance condition I propose simply requires the absence of any dealbreakers. ${ }^{41}$ In Strohl's terms, a necessary condition of any person's enjoying Titanic is that they lack dealbreakers for it; having lost loved ones at sea is probably a dealbreaker.

The key normative point is this: even though, descriptively speaking, some viewers have dealbreakers for Titanic, their dealbreakers do not give the rest of us moral reason to avoid the film. For those who are able to take tragic pleasure in Titanic, enjoying it is not morally wrong.

Descriptively speaking, many people cannot get sufficient emotional distance from the Holocaust to enjoy fictive depictions of Holocaust suffering. Holocaust imagery in the context of horror films is, for most of us, a Strohlian dealbreaker. But Holocaust imagery is not a dealbreaker for everyone. In some cases, we might worry that lacking dealbreakers for depictions of Holocaust violence is evidence of callousness or shameful ignorance, and it might be appropriate to blame them morally for those epistemic deficits or character flaws. But some people might blamelessly lack dealbreakers for Holocaust imagery. ${ }^{42}$ For those who blamelessly lack dealbreakers, it is not clear why their taking paradoxical pleasure in depictions of suffering and death in Nazi Cruelty Film would be morally different than the rest of us taking paradoxical pleasure in the suffering and death displayed for our entertainment in Titanic.

\section{Closing Comment on the Worry That This Article Is Frivolous}

Spasms of war have displaced millions, global warming is near the tipping point, the extinction rate continues to accelerate, and public confidence in democratic institutions continues to erode. Isn't an article defending the moral permissibility of renting Blood Feast, an article that draws its epigraph from the sixth instalment of the Friday the 13 th franchise... frivolous?

Glib responses get at something true. The question of the moral permissibility of gorefests has mattered a great deal to specific people in the not-so-distant past, including those retailers and distributors the British government targeted during the Video Nasty panic of the 1980s. Also glib but true: a question taken up by both Aristotle and Hume is probably not frivolous. ${ }^{43}$

The response I would rather endorse is this: controversy over the permissibility of enjoying gory fictions functions as a case study in the ease with which feelings of disgust can erode cosmopolitan commitments.

At the amusement park, we have no trouble allowing each other the space to choose the pains that paradoxically bring us pleasure and to avoid the pains that don't. Some enjoy the freefall of plunging rides but cannot tolerate the spinning of the teacups. Some enjoy extreme roller coasters, snug in their shoulder restraints, but panic in the open air of the Ferris wheel. Different bodies react differently to the ersatz threats these rides are designed to impose, and I know no one inclined to mistake this bodily variation for moral deformity.

Roger Ebert, film critic and famously open-hearted humanist, wrote this in his review of Wolf Creek (2005), an Australian horror film: 'The theaters are crowded right now with wonderful, thrilling, funny, warm-hearted, dramatic, artistic, inspiring, entertaining movies. If anyone you know says this is the one they want to see, my advice is: 
Don't know that person no more. ${ }^{44}$ Why does Ebert, who would not dream of condemning in moral terms people who enjoy Ferris wheels, condemn those who enjoy Wolf Creek? By way of conclusion, I would like to speculate about a possible answer.

Gore fans appear to be a minority of the general population. Saw (2004) was a towering blockbuster judged by the standard of other gorefests. It was profitable enough to spawn a franchise and notorious enough to become a household name; its lifetime box office gross ranks it only the 57th most successful film of 2004. Saw II (2005) was the most successful film of the franchise and arguably the most successful gore film of all time; it was the 21 st most successful film of $2005 .{ }^{45}$ The box-office evidence suggests that most people don't enjoy watching gore films. To the majority, for whatever reason, the fear and disgust gore films aim to cause is not paradoxically pleasant.

We have, then, a situation in which a numerical minority willingly engages in a practice that is disgusting to the majority. We have seen similarly structured situations before, with other minority groups and other practices. We should expect, based on those experiences, that the gulf of understanding between people who enjoy gore films and people who find them merely disgusting will leave members of the majority prone to believe there is something morally amiss with those others who choose to indulge in disgusting things. ${ }^{46}$

But feelings of disgust are an unreliable guide to morality. ${ }^{47}$ Most philosophers now embrace some version of cosmopolitanism about innocent differences in taste and practice, at least in the kitchen and the bedroom. This lesson was hard won, and the world is a better place for it: the dishes that are strange to you might, if you give them the chance, turn out to be worth celebrating, and even if not, they will probably turn out to be worth accepting as morally neutral variation.

About this most of us agree: we should in general take care to avoid mistaking innocent variation for moral degradation. That so many of us fail to adopt this attitude toward differences of taste in the movie theatre is an object lesson in the insidiousness with which feelings of disgust can manipulate us into mistaking our stomach for our conscience. Controversy around gore films thus refreshes a lesson too easy to forget: when our feelings of disgust are activated by the practices of another, we are at special risk of embracing weak arguments that invite us to escalate personal taste into misguided righteousness.

Ian Stoner, Department of Philosophy, Saint Paul College, 235 Marshall Ave, St Paul, MN, 55102,USA.ian.stoner@saintpaul.edu

\section{Acknowledgements}

Thanks to an associate editor and two anonymous reviewers at Journal of Applied Philosophy for their careful reading and feedback. Thanks to Crystal Bergstrom, Jason Swartwood, and Ruth Swartwood for discussion and feedback on developing drafts. Special thanks to Ruth for demanding a reckoning.

\section{NOTES}

1 In the early 1980s, UK law did not subject home video releases to the same certification and censorship processes as theatrical releases. As the price of VCRs and videotapes fell, unregulated videos, many of 
them graphically violent horror films, flooded the market. The result was a moral panic. The public outcry about these 'Video Nasties', as the tabloids called them, prompted the Video Recordings Act of 1984. The Act gave the government sweeping powers to ban videos from distribution, mandate draconian edits, confiscate inventory from retailers, and imprison distributors who violated the law. For a history of the Video Recordings Act that pays special attention to the moral claims that motivated it, see Julian Petley, “"Are We Insane?”. The "Video Nasty" moral panic', Recherches sociologiques et anthropologiques 43,1 (2012): 35-57.

2 Torturing and killing animals for entertainment is wrong, and my own view is that deriving entertainment from footage of animal killings is indefensible. Many horror fans share this position. Though horror fans hope to experience physical reactions of disgust and fear, most understand fiction to be part of the 'contract' between filmmaker and viewer: 'Despite any spectatorial anxiety, fainting or nausea made possible by watching horror films, viewers may still leave the theatre with the comforting thought that what was witnessed on-screen was an illusion' (Donald L. Anderson, 'How the horror film broke its promise: Hyperreal horror and Ruggero Deodato's Cannibal Holocaust', Horror Studies 4,1 (2013): 109-125, at p. 110). Films such as Cannibal Holocaust (1980) that break this implied contract are controversial and unwanted by many horror fans. For its Blu-ray release of Cannibal Holocaust, Grindhouse Releasing included an animal-cruelty-free re-edit of the film, at the request of fans who wanted to watch the movie, but didn't want to risk glimpsing any moment of the real animal killings.

3 Scott Woodcock, 'Horror films and the argument from reactive attitudes', Ethical Theory and Moral Practice 16,2 (2013): 309-324, at p. 310.

4 Ibid., p. 313.

5 One way to understand this conclusion is as comparative: there is something specially worrying about the kind of over-the-top graphic violence characteristic of gorefests. I believe Di Muzio's version of the ARA is comparative, and historical and present-day public debates about media violence standardly highlight extreme horror films as comparatively worrying. Scott Woodcock's position in 'Horror Films and the Argument from Reactive Attitudes' is not obviously comparative. He is clear that there are non-violent films that might damage our reactive attitudes (p. 316), and there are violent films that might be permissible by the lights of the ARA (p. 323). It is possible that Woodcock frames his article in terms of horror films as one of many equally good entry points into a discussion of the ARA, and not because he believes horror violence is more likely than any other kind of violence to violate the ARA. (Thanks to an anonymous reviewer for advocating for this as the most charitable reading of Woodcock.). The argument I develop in Section 2 is addressed explicitly to comparative understandings of the ARA. But I hope that the examples I introduce there will also contribute indirectly to discussions of non-comparative understandings of it.

6 David Gregory, Ban the Sadist Videos! Part 2 (Anchor Bay Entertainment, 2006), at 5:48-6:14.

7 For journalistic reports of worker experiences, see Virgil Butler and Laura Alexander, 'Whistleblower on the Kill Floor', Satya, 2006. Online at http://www.satyamag.com/feb06/butler.html. Accessed 15 April 2019, and Gail Eisnitz, Slaughterhouse: The Shocking Story of Greed, Neglect, And Inhumane Treatment Inside the U.S. Meat Industry (Prometheus Books, 2009). For a statistical analysis of the sociological data, see Amy Fitzgerald, Linda Kalof and Thomas Dietz, 'Slaughterhouses and increased crime rates: an empirical analysis of the spillover from "The Jungle" into the surrounding community', Organization E Environment 22,2 (2009): 158-184.

8 As if we needed it: predictable psychological harm to slaughterhouse workers yields yet another moral reason for the rest of us to stop buying meat. See Carl Hammer, 'Dependence on wrongdoing in the consumption of meat: a Kantian analysis', fournal of Applied Philosophy 31,2 (2014): 169-187.

9 American Psychological Association et al., Joint Statement on the Impact of Entertainment Violence on Children, 26 July 2000. Online at https://www.iianthropology.org/psychology_childrenviolence.html.

10 See, e.g. John Gramlich, '5 facts about crime in the U.S.' Pew Research Center. Online at https://www.pe wresearch.org/fact-tank/2019/01/03/5-facts-about-crime-in-the-u-s/. Accessed 27 April 2019.

11 See Patrick Markey, Charlotte Markey, and Juliana French, 'Violent video games and real-world violence: rhetoric versus data', Psychology of Popular Media Culture 4,4 (2015): 277-295.

12 Two sceptical perspectives published around the time of the Joint Statement were Richard Rhodes, 'The media-violence myth', Rolling Stone, 2000: 55-558 and Jonathan L. Freedman, Media Violence and Its Effect on Aggression: Assessing the Scientific Evidence (Toronto, ON: University of Toronto Press, 2002). For a literature review that examines the details and design flaws of many well-known studies, see Chapter 2 of Katherine Allen, 'What joy from misery: the pleasures of horror' (Doctoral Dissertation, University of 
East Anglia, 2012). Online at https://ueaeprints.uea.ac.uk/42350/. Accessed 6 April 2019. Her conclusion: 'Although vocal opponents of violent media employ analogies which suggest that the case is already closed... the alleged perils of media violence actually remain highly contentious, with the body of effects research leaving considerably more room for alternative interpretations than such comparisons imply' ( $p$. 66).

13 Christopher J. Ferguson and John Kilburn, 'The public health risks of media violence: a meta-analytic review', The Fournal of Pediatrics 154,5 (2009): 759-763, at 759.

14 Woodcock op. cit., p. 313.

15 Samuel Johnson was so convinced of Titus's depravity and Shakespeare's decency that he refused to believe Shakespeare wrote the play. He interpreted Titus's early popularity as evidence of the immorality of Elizabethan audiences: 'The barbarity of the spectacles, and the general massacre, which are here exhibited, can scarcely be conceived tolerable to any audience; yet we are told by [Ben] Jonson, that they were not only borne but praised' (Samuel Johnson, The Works of Samuel fohnson, LL. D.: With an Essay on His Life and Genius Volume VI (New York, NY: Dearborn, 1832), at p. 489). My claim that there is nothing wrong with enjoying Titus is not an analytical truth. However, a recent controversy concerning a Cambridge University teaching associate's use of a trigger warning for Titus Andronicus is evidence that the permissibility of the play is now effectively unquestioned. The controversy at Cambridge was not about whether the violence in Titus makes it morally wrong to assign it, but rather about whether the torture, rape, and murder portrayed in Titus is so innocuous that the instructor's use of a trigger warning constituted a wrongful coddling of his students. See Ian Burrows, 'Warning my students about a lecture on assault does not make them snowflakes'. Online at https://www.theguardian.com/commentisfree/2017/ oct/31/shakespeare-trigger-warning-students-snowflakes-cambridge-university-sexual-abuse-victims.

Accessed 20 August 2019.

16 A central question in philosophical aesthetics: should moral defects in a work of art count against its aesthetic evaluation? The position suggested here inverts that question - should aesthetic defects count against a work's moral evaluation? - and assumes an affirmative answer.

17 Gianluca Di Muzio, 'The Immorality of Horror Films', International fournal of Applied Philosophy 20,2 (2006): 277-294, at p. 290.

18 Both of these 'torture porn' franchises are cultural artefacts of the second Bush administration's torture regime, and that context might be relevant to an attempt to read them for meaning. See Aaron Michael Kerner, Torture Porn in the Wake of 9/11: Horror, Exploitation, and the Cinema of Sensation (New Brunswick, NJ: Rutgers University Press, 2015).

19 Alan Jones, The Rough Guide to Horror Movies, Vol. 1 (London: Rough Guides, 2005), p. 158.

20 For more on this point, see Philip Nickel, 'Horror and the idea of everyday life: on sceptical threats in psycho and the birds' in T. Fahy (ed.) The Philosophy of Horror (Lexington, KY: University Press of Kentucky, 2010): 14-32.

21 Roger Ebert, 'Why Movie Audiences Aren't Safe Anymore', American Film, 1981: 54-56.

22 Linda Williams, 'When the woman looks' in M. A. Doane (ed.) Re-vision: Essays in Feminist Film Criticism (University Publications of America, 1984): 83-99.

23 Xavier Aldana Reyes, Horror Film and Affect: Towards a Corporeal Model of Viewership (London: Routledge, 2016), p. 100.

24 How can gore fans enjoy feelings of fear and disgust inside movie theatres when these are unwanted feelings outside of them? That is a fascinating psychological question whose answer is probably irrelevant to the moral challenge posed by the ARA. People can, in some contexts, enjoy feelings of fear and disgust. (See Nina Strohminger, 'The Hedonics of Disgust' (Doctoral Dissertation, University of Michigan, 2013).) That is why they ride roller coasters, buy tickets for haunted hayrides, sniff the spoiled milk, and watch YouTube videos of people popping pimples. We need not wait on a psychological explanation of hedonic disgust to note that gore fans enjoy feelings of fear and disgust at the movies or to ask if that enjoyment is morally permissible.

25 Reyes makes a similar point about the revenge killings in I Spit on Your Grave (2010): even though our moral sympathies align with the killer, her killings are coded as moments of horror, not vicarious sadism (Reyes op. cit, p. 99).

26 Carol J. Clover, 'Her body, himself' in Men, Women, and Chain Saws: Gender in the Modern Horror Film (Princeton, NJ: Princeton University Press, 1992): 21-64.

27 Adam Charles Hart, 'Killer POV: First-person camera and sympathetic identification in modern horror', Imaginations: Fournal of Cross-Cultural Image Studies 9,1 (2018): 69-86, at p. 77. 
28 Nickel op. cit., p 16.

29 Cynthia A. Freeland, The Naked and the Undead: Evil and the Appeal of Horror (Westview Press, 2000), p. 267.

30 See Noël Carroll, The Philosophy of Horror, Or, Paradoxes of the Heart (London: Routledge, 1990).

31 Reyes op. cit., p. 1 and pp. 121-126.

32 See Berys Gaut, 'The Paradox of Horror', The British fournal of Aesthetics 33,4 (1993): 333-345.

33 There probably are individual viewers who derive vicarious sadistic pleasure from gore films. This is not a moral mark against the genre. I suppose that somewhere there are neo-Nazis who love Schindler's List for all the wrong reasons. Their orientation of vicarious sadism is a moral failure of them as viewers, not a mark against the film.

$34 \mathrm{My}$ thesis in this article is that watching horror violence does not plausibly damage our appropriate reactive attitudes; for any gorefest you might imagine, its displays of violence are not a moral problem. That is compatible with conceding, as I do, that watching racist, or sexist, or vicariously sadistic movies of any genre could plausibly damage our appropriate reactive attitudes. Any one of these moral failings can occur accompanied by, or not accompanied by, depictions of violence.

35 I am here endorsing the same conditionals proposed by Martin Zuckerman, a psychologist who studied audience responses to horror films as part of a broader research programme on sensation-seeking behaviours: 'If we assume that latent aggressive impulses are the only trait that might account for the taste for vicarious horror, one should be alarmed at the possible consequences of viewing such films.... However, if sensation seeking is a prominent motive and fright arousal... is the main source of reward, then such films are probably innocuous' (Marvin Zuckerman, 'Sensation Seeking and the Taste for Vicarious Horror' in J. Weaver and R. Tamborini (eds.) Horror Films: Current Research on Audience Preferences and Reactions (Lawrence Erlbaum Associates, 1996): 147-160, at pp. 158-159).

36 Di Muzio op. cit., p. 281.

37 Ibid., p. 282.

38 Di Muzio anticipates the objection that Nazi death camps were real, while movie slashers are imaginary. He replies that connection to real-world suffering is not a genuine marker of difference between Nazisploitation films and most other gorefests: 'Homicidal maniacs exist in reality and... subject their victims to atrocities as perversely creative as those depicted in gorefest films' (Ibid, p. 283). The famously low quality, lack of ambition, and general sleaziness of Nazisploitation films, on the other hand, is a genuine marker of difference between them and most other gorefests. These differences in artistic merit and meaningfulness, however, are not morally relevant to Di Muzio's argument; this is the flip side of the case I made in Sections 2.1 and 2.2. A more fundamental worry is that Di Muzio is fallaciously generalising from a non-arbitrary case: it is morally wrong to watch this imaginary Nazisplitation film; therefore it is wrong to watch all gore films. But Di Muzio is careful not to do that. He intends to draw our attention to an especially clear-cut case, and then he suggests that gorefests in general share that case's morally relevant features.

39 For more on this methodological point, see Ian Stoner and Jason Swartwood, 'Fanciful Examples', Metaphilosophy 48,3 (2017): 325-344, especially pp. 330-333.

40 Winfried Menninghaus et al., 'The Distancing-Embracing model of the enjoyment of negative emotions in art reception', Behavioral and Brain Sciences 40 (2017).

41 Matthew Strohl, 'Art and painful emotion', Philosophy Compass 14,1 (2019): e12558, at p. 8.

42 For example, people raised in cultures that do not teach European history are likely to be epistemically and emotionally distant from the Holocaust relative to those of us who still live in its shadow. Among those with little European history, the absence of dealbreakers for Holocaust imagery need not be a moral failure. By way of analogy: the Spanish Inquisition is epistemically and emotionally distant for me, which is why I can enjoy Monty Python. Without denying or minimising the enormity of the atrocities committed during the Inquisition, I think I can blamelessly lack dealbreakers for Inquisition imagery.

43 E. M. Dadlez, 'Spectacularly bad: Hume and Aristotle on tragic spectacle', fournal of Aesthetics and Art Criticism 63, (2005): 351-358.

44 Roger Ebert, 'Wolf Creek Movie Review \& Film Summary', 2005. Online at https:/www.rogerebert.com/ reviews/wolf-creek-2005. Accessed 18 April 2019.

45 Box office numbers gathered from https://www.boxofficemojo.com/yearly/chart/?yr=2004 and https:// www.boxofficemojo.com/yearly/chart/?yr=2005. Accessed 31 August 2019.

46 For an overview of this phenomenon playing out in the context of social and legal attitudes toward samesex relationships, see Martha C. Nussbaum, From Disgust to Humanity: Sexual Orientation and Constitutional Law (Oxford, Oxford University Press, 2010). 
47 Few would deny this claim. It is too clear from examples, including common reactions to facial deformities, unfamiliar cuisines, and spiders, that 'the fact that something is disgusting is not even remotely a reliable indicator of foul play' (Daniel Kelly, Yuck! The Nature and Moral Significance of Disgust (Cambridge, MA: MIT Press, 2011), at p. 148). Philosophers who offer arguments in defence of a connection between disgust and morality defend claims more carefully qualified than 'repugnance is the emotional expression of deep wisdom' (Leon Kass, 'The Wisdom of Repugnance', The New Republic, 1997: 17-26, at p. 20). Mary Midgley, for example, argues that a disgust response should prompt moral scrutiny of the thing that caused it (which is what I have tried to do here) and Alexandra Plakias argues that feelings of disgust can in some cases be a fitting response to social norm violations (which is compatible with the position I defend here). See Mary Midgley, 'Biotechnology and Monstrosity: Why We Should Pay Attention to the "Yuk Factor"', Hastings Center Report 30,5 (2000): 7-15, and Alexandra Plakias, 'The response model of moral disgust', Synthese 195,12 (2018): 5453-5472. 